\title{
A study on the transmission of helicobacter pylori from food prepared and consumed under hygienic and unhygienic conditions: A first study using biopsy samples
}

\author{
Khawaja Shakeel Ahmed ${ }^{1 *}$, Basheer Madompoyil ${ }^{2}$, Janak Dulari Ahi ${ }^{3}$, Aleem Ahmed Khan ${ }^{4}$, \\ Santosh Kumar Tiwari ${ }^{4}$, Mohammed Aejaz Habeeb ${ }^{4}$ \\ ${ }^{1}$ Asmara College of Health Sciences, Department of Clinical Laboratory Sciences, Microbiology Unit, Asmara, Eritrea; \\ *Corresponding Author: khajashakeel@gmail.com \\ ${ }^{2}$ Orotta School of Medicine and Dentistry, Asmara, Eritrea \\ ${ }^{3}$ Dr. Hari Singh Gour University, Sagar Madhya Pradesh, India \\ ${ }^{4}$ Centre for Liver Research and Diagnostics, Deccan College of Medical Sciences, Hyderabad, India
}

Received 24 November 2013; revised 30 December 2013; accepted 7 January 2014

Copyright (C) 2014 Khawaja Shakeel Ahmed et al. This is an open access article distributed under the Creative Commons Attribution License, which permits unrestricted use, distribution, and reproduction in any medium, provided the original work is properly cited. In accordance of the Creative Commons Attribution License all Copyrights @ 2014 are reserved for SCIRP and the owner of the intellectual property Khawaja Shakeel Ahmed et al. All Copyright @ 2014 are guarded by law and by SCIRP as a guardian.

\section{ABSTRACT}

Objective: A comparative analysis on transmission of Helicobacter pylori in people who consumed food prepared in both hygienic and unhygienic conditions. Method: The study was carried out in 1000 people across India. The Ratio of Male: female was 700: 300 with age group ranging from 20 - 39. Three gastric biopsies were collected for identification of Helicobacter pylori. PCR (Polymerase Chain Reaction) amplification was done by using 16srRNA primers. Result: The analysis showed the prevalence of $H$. pylori as $70.8 \%$ in individuals frequently consuming food prepared under less hygienic condition (street vendor's food) whereas $60 \%$ (less prevalence) in individuals consuming food prepared under hygienic conditions. Conclusion: The results showed that most of the food that we consume daily is not involved much in the transmission of Helicobacter pylori. The study also showed that the street vendor's food is not directly involved in the transmission of this bacterium. The unhygienic preparation of food and poor personal hygiene play a vital role in the transmission of these bacteria.

\section{KEYWORDS}

Helicobacter pylori; Hygiene; PCR; 16SrRNA;

\section{Food; Biopsy}

\section{INTRODUCTION}

After the isolation and identification of Helicobacter pylori in 1982 [1], irresistible data have been drawn in showing Helicobacter pylori as an etiologic component of chronic gastritis, peptic ulcer, and gastric cancer [2-8]. Successful control of this chronic infection would reduce the incidence of gastritis and peptic ulcer, and it may remarkably lower the rates of one of the world's deadliest neoplasm. Understanding the public health impact of $H$. pylori infection, attention must be given to identification of preventive measures. Opposite to their success in developed countries, anti- $H$. pylori therapies have proven to be much less successful in populations where this infection is most prevalent $[9,10]$ apparently in part due to reinfection $[11,12]$.

Ways of preventing reinfection have not been identified, because the mode of transmission still remains obscure [13]. Knowledge regarding the epidemiology of $H$. pylori came largely from seroprevalence studies. Studies designed to study the incidence of $H$. pylori were limited because of the difficulty in identifying incident cases [14]. In addition, the insufficient sensitivity of available techniques for detecting $H$. pylori in materials other than gastric tissue has presented hurdles to find out the exact mode of entry and exit, and to identify or rule out environmental reservoirs. Most researchers believe that the 
infection occurs through person to person transmission $[15,16]$. Evidence to support both fecal-oral and oral-oral routes has been reported [17-21], while some findings support the possibility of water-borne transmission [2226]. Some earlier studies have also shown the role of diet in the prevalence and transmission of $H$. pylori taken from street vendors [27]. An earlier study done in CALCUTTA showed that street food was prone to microbiological contamination. In the same study the researchers showed that the water used for drinking, cooking, washing of fruits and vegetables, dishwashing, hand washing, etc. was found to be contaminated in 47 percent of samples analyzed. It should be noted that the water source was safe but contaminated through poor handling [28].

The hazards in most of the food samples arise due to poor personal hygiene, extended holding, continual handling and the use of poor quality water and apparatus at different stages of preparation [28].

In South Indian population, the prevalence of Helicobacter pylori is seen increasing with age, and reaching $100 \%$ at the age of 80 . Other than age, other factors too are found to be associated with higher infection rate of Helicobacter pylori. Among them there are poor socio-economic status, poor drinking water facility, [29] and lack of maintenance of proper hygienic conditions in the houses [30].

Till date, no study has reported a comparative study of the incidence of Helicobacter pylori among the people consuming food prepared under less hygienic conditions (street vendor's food) with those who take the same food in good hygienic conditions.

The main objective of this study was to identify the role of food prepared and consumed in less hygienic condition in the transmission of $H$. pylori by taking an example of street vendor's food, since previous studies done all over the world showed the impact of street vendor's food in the causation of various chronic disorders. This was compared with the food prepared and consumed under good hygienic conditions with the help of PCR assay.

Many PCR assays have been developed for the identification of Helicobacter pylori because it has been proved that PCR provides a highly specific and highly sensitive method of detecting microbial pathogen in clinical specimen [29].

The present study is designed in such a way that all the subjects selected were of same age group and same socio-economic status.

\section{MATERIALS AND METHODS}

Total 1020 individuals were selected randomly, attending the Gastroenterology Clinic of Deccan College of Medical Sciences with upper gastrointestinal tract symptoms. 20 subjects were excluded because of false dietary habits remaining, 1000 subjects were enrolled for the study (700 Males 300 Females) of age group ranging from 20 - 39, (Average Age 34.9) with lower socioeconomic status, measured by Hollings head Index [31].

Patients subjected to PPI (Proton Pump Inhibitor) or any antibiotic therapy was excluded from the study. Those subjects who were attending the gastroenterology clinic for repeat endoscopy or have any previous history of Helicobacter pylori infection were not included in the study. The patients selected were divided among 2 groups.

The $1^{\text {st }}$ group of 500 patients enrolled in the study was asked to fill a questionnaire. They were questioned regarding the presence and the regularity of the symptoms such as indigestion, heartburn, vomiting sensation, and frequency of epigastric or hypochondrial pain. Dietary data was collected from the individuals participating in the study; which included about the frequency of consumption of outside food (Daily, Once/Week, Once/ Month, /Never) mainly Chicken, Fish, Beef, Milk, Fruits, Vegetables, and other Food items (like lassi, sherbets, cut fruits and curry juices) from street vendors. Care was taken that the dietary data provided represents the current practice of the individuals.

The $2^{\text {nd }}$ group of 500 patients which were considered as control was strictly selected using certain parameters (Table 1). Those subjects who were following all those parameters strictly, personally or in their homes were included in the study.

The above parameters used in our study have no previous validation, our study is the first, who used it by assume that these factors are enough to represents the good hygienic environment while cooking and dispensing food. These subjects were also questioned regarding the presence and the regularity of the symptoms such as indigestion, heartburn, vomiting sensation, and frequency of epigastric or hypochondrial pain.

Samples to assess $H$. pylori infection included three

Table 1. Parameters used for selection of $2^{\text {nd }}$ group of subjects

\begin{tabular}{|c|c|}
\hline S. No & Parameters Used For Selection of Subjects \\
\hline 1 & $\begin{array}{c}\text { Before preparing, or dispensing food, hands are washed } \\
\text { with soap or ash. }\end{array}$ \\
\hline 2 & $\begin{array}{l}\text { Raw fruits and vegetables are not taken unless they are } \\
\text { first peeled or washed with clean water. }\end{array}$ \\
\hline 3 & $\begin{array}{l}\text { Fresh meat are cooked and eaten on the same day, unless } \\
\text { it is stored in a refrigerator. }\end{array}$ \\
\hline 4 & $\begin{array}{l}\text { Cooked food is eaten while it is hot and should not be } \\
\text { left at room temperature for longer period of time. }\end{array}$ \\
\hline 5 & $\begin{array}{l}\text { Serving dishes, plates and cutlery should be spotlessly } \\
\text { clean and should be washed thoroughly. }\end{array}$ \\
\hline
\end{tabular}


gastric biopsies collected in phosphate buffer saline for DNA isolation and PCR assay. Genomic DNA was extracted from all samples as per the standard protocol using Cetyltrimethyl ammonium bromide (CTAB) method. Two 20-base oligonucleotide primers designated 16S rRNA-F (5' TAAGAGATCAGCCTATATGTCC-3') and 16S rRNA-R (5' TCCCACGCTTTAAGCGCAAT3’) as reported in our earlier study was selected (29).

The DNA prepared from the clinical isolates and from the type strain of $H$. pylori (ATCC 26695) gave an amplified product 534 bp long, using these primers. PCR amplification was performed. An initial denaturation was done at $95^{\circ} \mathrm{C}$ for 5 minutes followed by 40 cycles, each cycle consisting of $30 \mathrm{sec}$ at $94^{\circ} \mathrm{C}, 30 \mathrm{sec}$ at $56^{\circ} \mathrm{C}, 1$ minute at $72^{\circ} \mathrm{C}$. The final cycle included a 10 minute extension step at a temperature of $72^{\circ}$ to ensure full extension of the PCR products. Amplification was performed in a thermocycler (M J Research Inc, Water town, USA). DNA of the ATCC type strain was used as a positive control while all the reagents of the master mix except the template DNA was taken as negative control in each set of PCR assays. The PCR-amplified products were analyzed by agarose gel electrophoresis; Samples were scored as positive when a band of 534 bp could be detected on agarose gel (Figure 1 ).

\section{Statistical Analysis}

Statistical analysis was done using multiple logistic regression models. These models help to assess the relative importance of $H$. pylori risk factors. The data was analyzed using the SPSS 12.0 (Chicago, IL, USA.). The models used in the study have not adjusted for factors like socio-economic status, age or other parameters responsible for transmission of Helicobacter pylori.

\section{RESULTS}

A total of 1000 individuals were screened for Helicobacter pylori.

In the $1^{\text {st }}$ group of 500 patients, 354 were found positive $(70.8 \%)$ for Helicobacter pylori, which was con- firmed by positive 16SrRNA amplification of the DNA isolated, out of 354, 280 were males and 74 females. In addition to this we also studied the prevalence of Helicobacter pylori by consuming food items purchased from street vendors. Hence, we analyzed those who consumed chicken daily from street vendors. Results showed a prevalence of $82.6 \%$. Similarly, those individuals who consumed street vendor's food once/week and once/ month the prevalence got decreased. Those who consumed it less than once/month (considered as never) showed less prevalence of Helicobacter pylori (Tables 2 \& 3). Systematically we also analyzed the prevalence of Helicobacter pylori by consumption of fish. The study revealed that those individuals who daily consumed fish showed a prevalence of $81.8 \%$. While with the decrease of consumption of fish from street vendor's the prevalence also decreased. And reaching up to less than once/month (considered as never) the prevalence of $\mathrm{He}$ licobacter pylori came down to 50\% (Tables $2 \& 3$ ).

Similarly, those individuals who frequently consumed beef from street vendors showed the prevalence of $81.1 \%$. While those who are consumed it once/week and once/ month showed the prevalence of $71.9 \%$ and $60 \%$ respectively. Among those individuals who totally avoided beef

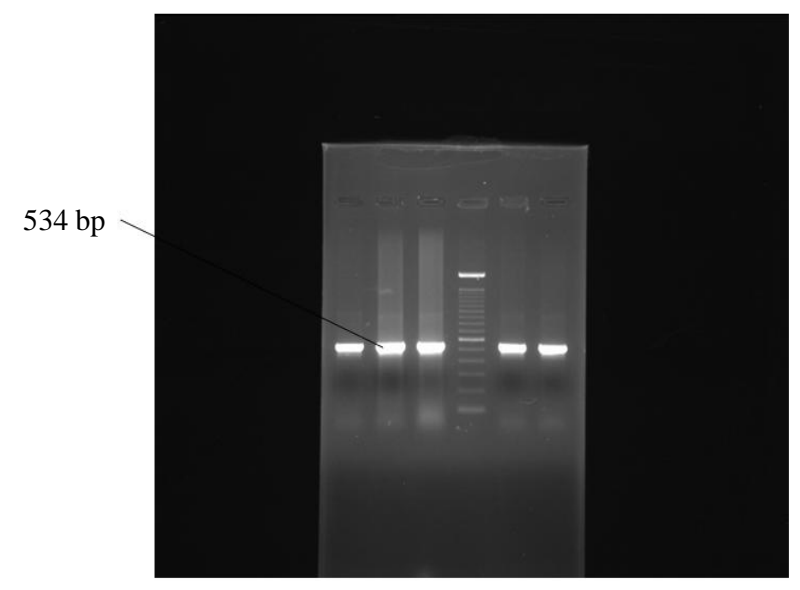

Figure 1. Positive amplification of 16SrRNA gene of Helicobacter pylori.

Table 2. Prevalence of Helicobacter pylori in the subjects taking food under Un-hygienic Conditions (street Vendor's Food).

\begin{tabular}{cccccc}
\hline S.No & Food Items & Daily & Once/Week & Once/Month & Never \\
\hline 1 & Chicken & $230 / 190(82.6 \%)$ & $170 / 115(67.6 \%)$ & $40 / 20(50 \%)$ & $60 / 29(48.3 \%)$ \\
2 & Fish & $220 / 180(81.8 \%)$ & $180 / 120(66.6 \%)$ & $50 / 29(58 \%)$ & $50 / 25(50 \%)$ \\
3 & Beef & $228 / 185(81.1 \%)$ & $164 / 118(71.9 \%)$ & $25 / 15(60 \%)$ & $83 / 36(43.3 \%)$ \\
4 & Milk & $210 / 184(87.6 \%)$ & $150 / 100(66.6 \%)$ & $70 / 40(57.1 \%)$ & $70 / 30(42.8 \%)$ \\
5 & Fruits & $220 / 194(88.1 \%)$ & $140 / 90 .(64.2 \%)$ & $90 / 50(55.5 \%)$ & $50 / 20(40 \%)$ \\
6 & Vegetables & $300 / 250(83.3 \%)$ & $100 / 60(60 \%)$ & $40 / 20(50 \%)$ & $60 / 24(40 \%)$ \\
7 & Other Food Items & $187 / 170(90.9 \%)$ & $80 / 58(72.5 \%)$ & $116 / 76(65.5 \%)$ & $117 / 50(42.7 \%)$ \\
\hline
\end{tabular}


Table 3. Prevalence of Helicobacter pylori in the subjects taking food in un-hygienic conditions (street Vendor's food) assessed by multiple logistic regression.

\begin{tabular}{ccccccccccc}
\hline S.No & Food Item & \multicolumn{2}{c}{ Daily } & \multicolumn{2}{c}{ Once/Week } & \multicolumn{2}{c}{ Once/Month } & \multicolumn{2}{c}{ Never } \\
\hline & & $\begin{array}{c}\text { Odds } \\
\text { Ratio }\end{array}$ & $\begin{array}{c}\text { 95\% CI } \\
\text { Lower-Upper }\end{array}$ & $\begin{array}{c}\text { Odds } \\
\text { Ratio }\end{array}$ & $\begin{array}{c}\text { 95\% CI } \\
\text { Lower-Upper }\end{array}$ & $\begin{array}{c}\text { Odds } \\
\text { Ratio }\end{array}$ & $\begin{array}{c}\text { 95\% CI } \\
\text { Lower-Upper }\end{array}$ & $\begin{array}{c}\text { Odds } \\
\text { Ratio }\end{array}$ & $\begin{array}{c}\text { 95\% CI } \\
\text { Lower-Upper }\end{array}$ \\
\hline 1 & Chicken & 5.078 & $2.758-9.349$ & 2.235 & $1.227-4.071$ & 1.069 & $0.480-2.380$ & Referent & Referent \\
2 & Fish & 4.500 & $2.345-8.634$ & 2.000 & $1.060-3.774$ & 1.381 & $0.627-3.040$ & Referent & Referent \\
3 & Beef & 5.617 & $3.252-9.700$ & 3.349 & $1.929-5.815$ & 1.958 & $0.788-4.867$ & Referent & Referent \\
4 & Milk & 9.436 & $5.042-17.658$ & 2.667 & $1.489-4.775$ & 1.778 & $0.910-3.472$ & Referent & Referent \\
5 & Fruits & 11.192 & $5.567-22.501$ & 2.700 & $1.391-5.240$ & 1.875 & $0.929-3.784$ & Referent & Referent \\
6 & Vegetables & 7.500 & $4.120-13.654$ & 2.250 & $1.171-4.324$ & 1.500 & $0.669-3.361$ & Referent & Referent \\
7 & Other food Items & 13.400 & $7.218-24.876$ & 3.533 & $1.915-6.517$ & 2.546 & $1.499-4.325$ & Referent & Referent \\
\hline
\end{tabular}

from street vendors, the prevalence of Helicobacter pylori was only $43.3 \%$ (Tables $2 \& 3$ ).

Our next aim was to analyze the prevalence of Helicobacter pylori in relation to frequency of consumption of milk. Results showed that individuals who daily drinks milk purchased from street vendors showed a prevalence of $87.6 \%$.

While those who drink it once/week and once/month showed the prevalence which was comparatively low, those who drink it less than once/month (considered as never) the prevalence of Helicobacter pylori was, $42.8 \%$ (Tables 2 \& 3).

Analyzing fruits as another food item to be identified for the prevalence of Helicobacter pylori in relation to its frequency of consumption from street vendors, we found that those individuals who consumed fruits everyday showed the prevalence of $88.1 \%$. Meanwhile those who consumed it once/week and once/month showed less prevalence. While those individuals who are taking it less than once a month (considered as never) showed less prevalence i.e., $40 \%$ (Tables $2 \& 3$ ).

We also analyzed the prevalence of Helicobacter pylori in relation to frequency of consumption of raw vegetables. We found that individuals who consumed uncooked vegetables in daily diet showed the prevalence of $83.3 \%$.

While those individuals who consumed it once/week and once/month showed the prevalence of $60 \%$ and $50 \%$ respectively, Individuals who took raw vegetables less than once/month (considered as never) showed a prevalence of Helicobacter pylori of $40 \%$ (Tables $2 \& 3$ ).

Next we investigated the prevalence of Helicobacter pylori in relation to frequency of consumption of other food items bought and consumed from street vendors. We found those individuals who are consumed it daily showed the prevalence of $90.9 \%$, while those who consumed the food items once/week and once/month the prevalence was less. And individuals who never took those food items from street vendors showed a low pre- valence of $42.7 \%$ (Tables $2 \& 3$ ).

In the same way when we screened the prevalence of Helicobacter pylori in the $2^{\text {nd }}$ group of 500 individuals, $60 \%(300 / 500)$ of them were found positive. Of the 300 , 250 were males and 50 females. This was confirmed by 16SrRNA amplification of the isolated DNA.

This group was first analyzed for the prevalence of Helicobacter pylori while preparing and consuming chicken daily by following the guidelines given in Table 1. We found a prevalence of $68.3 \%$.Those who consumed it once/week and once/month showed the prevalence of $55 \%$ and $40 \%$ respectively. And those who consumed it less than a month (considered as never) showed a prevalence of $40 \%$ (Tables $4 \& 5$ ).

Similarly we analyzed the prevalence of Helicobacter pylori in those individuals who prepared and consumed fish daily, showed a prevalence of $68 \%$. Those individuals who are taking it in less frequency the prevalence decreased. And those who consumed it less than a month (considered as never) showed a considerable decrease in the prevalence of Helicobacter pylori (Tables $4 \& 5$ ).

Next we screened the prevalence of Helicobacter pylori in those who prepared and consumed beef daily in good hygienic environment, showed a prevalence of $66.6 \%$. The individuals who consumed it once/week and once/month showed less prevalence. While those individuals who avoided beef in their diet showed a prevalence of $43.3 \%$ (Tables 4 \& 5).

Individuals whose daily diet includes milk showed a prevalence of $67.5 \%$. Individuals who drink milk once/ week and once/month under hygienic environment showed less prevalence. While those subjects who totally avoided drinking milk showed a prevalence of $50 \%$ (Tables 4 \& 5).

When individuals who frequently consumed fruits following the guidelines mentioned in Table 1 the prevalence of Helicobacter pylori was $50 \%$.

While those subjects who consumed it once/week and once/month the prevalence of Helicobacter pylori in 
Table 4. Prevalence of Helicobacter pylori in the subjects taking food under good Hygienic Conditions.

\begin{tabular}{cccccc}
\hline S.No & Food Items & Daily & Once/Week & Once/Month & Never \\
\hline 1 & Chicken & $250 / 110(44 \%)$ & $100 / 45(45 \%)$ & $100 / 45(45 \%)$ & $50 / 25(50 \%)$ \\
2 & Fish & $200 / 95(46.5 \%)$ & $170 / 79(46.4 \%)$ & $100 / 43(43 \%)$ & $30 / 10(33.3 \%)$ \\
3 & Beef & $300 / 135(45 \%)$ & $100 / 45(45 \%)$ & $75 / 35(46.6 \%)$ & $25 / 10(40 \%)$ \\
4 & Milk & $200 / 94(47 \%)$ & $130 / 58(44.6 \%)$ & $100 / 43(43 \%)$ & $70 / 30(42.8 \%)$ \\
5 & Fruits & $225 / 102(45.3 \%)$ & $125 / 56(44.8 \%)$ & $100 / 46(46 \%)$ & $50 / 21(42 \%)$ \\
7 & Vegetables & $230 / 110(47.8 \%)$ & $160 / 70(43.7 \%)$ & $35 / 15(42.8 \%)$ & $75 / 30(40 \%)$ \\
\hline
\end{tabular}

Table 5. Prevalence of Helicobacter pylori in the subjects taking food in under good hygienic conditions assessed by multiple logistic regressions.

\begin{tabular}{cccccccccc}
\hline S.No & Food Item & \multicolumn{2}{c}{ Daily } & \multicolumn{2}{c}{ Once/Week } & \multicolumn{2}{c}{ Once/Month } & \multicolumn{2}{c}{ Never } \\
\hline & & $\begin{array}{c}\text { Odds } \\
\text { Ratio }\end{array}$ & $\begin{array}{c}\text { 95\% CI } \\
\text { Lower-Upper }\end{array}$ & $\begin{array}{c}\text { Odds } \\
\text { Ratio }\end{array}$ & $\begin{array}{c}\text { 95\% CI } \\
\text { Lower-Upper }\end{array}$ & $\begin{array}{c}\text { Odds } \\
\text { Ratio }\end{array}$ & $\begin{array}{c}\text { 95\% CI } \\
\text { Lower-Upper }\end{array}$ & $\begin{array}{c}\text { Odds } \\
\text { Ratio }\end{array}$ & $\begin{array}{c}\text { 95\% CI } \\
\text { Lower-Upper }\end{array}$ \\
\hline 1 & Chicken & 0.786 & $0.428-1.443$ & 0.818 & $0.414-1.615$ & 0.818 & $0.414-1.611$ & Referent & Referent \\
2 & Fish & 1.738 & $0.775-3.901$ & 1.736 & $0.767-3.929$ & 1.509 & $0.641-3.552$ & Referent & Referent \\
3 & Beef & 1.227 & $0.534-2.820$ & 1.227 & $0.503-2.994$ & 1.312 & $0.523-3.293$ & Referent & Referent \\
4 & Milk & 1.182 & $0.683-2.047$ & 1.074 & $0.598-1.930$ & 1.006 & $0.543-1.864$ & Referent & Referent \\
5 & Fruits & 1.145 & $0.616-2.129$ & 1.121 & $0.577-2.175$ & 1.176 & $0.593-2.335$ & Referent & Referent \\
6 & Vegetables & 1.375 & $0.810-2.335$ & 1.167 & $0.668-2.038$ & 1.125 & $0.499-2.537$ & Referent & Referent \\
7 & Other food Items & 1.269 & $0.586-2.750$ & 1.208 & $0.539-2.711$ & 1.227 & $0.535-2.814$ & Referent & Referent \\
\hline
\end{tabular}

creased. Those who consumed it less than once/month (considered as never) the prevalence was higher and reached up to $80 \%$ (Tables $4 \& 5$ ).

We also studied the prevalence of Helicobacter pylori in individuals who consumed raw vegetables daily in their diet the incidence was $52.1 \%$. While those who took it once/week and once/month showed a higher prevalence. Those subjects who never consumed it showed higher prevalence of $80 \%$ (Tables 4 \& 5).

Similarly, when we screened the prevalence of Helicobacter pylori in those subjects who consumed other food items daily the percentage of Helicobacter pylori was of $60.33 \%$. While those subjects who consumed it once/week and once/month showed a prevalence of $62.6 \%$ and $62.6 \%$ respectively, those who totally avoided such food showed a prevalence of 50\%. Logistic regression showed no significance (Tables 4 \& 5).

Logistic regression analysis of the whole data is shown in Table 6. Those who were taking food under un-hygienic conditions (street vendor's food), and those who are taking it in hygienic conditions were taken as referent.

\section{DISCUSSION}

Evaluation of dietary factors suggested that food con- sumed under unhygienic conditions (street vendor's food) might be a reason for contracting Helicobacter pylori infection. The unhygienic conditions in which food is prepared and dispensed by street vendors are well known. Our results showed that individuals who consumed food under unhygienic conditions (street vendor's food) showed high prevalence of Helicobacter pylori.

Comparative study showed that the prevalence of $\mathrm{He}$ licobacter pylori is higher in those subjects who take chicken under unhygienic conditions (street vendor's food) than those who consume it under good hygienic conditions.

This confirms that food prepared, handled, and dispensed in unhygienic conditions play an important role in the contamination of the food and in the transmission of bacterium even after cooking. Earlier studies shows that Helicobacter pylori survive a longer period of time at temperature below $30^{\circ} \mathrm{C}$ [32] and the temperature required for cooking chicken is $73^{\circ} \mathrm{C}$ [33].

Similarly, a higher prevalence of Helicobacter pylori was found in those subjects who consumed fish in unhygienic conditions (street vendor's food). When we compared it with the subjects who consumed the fish cooked under good hygienic conditions the prevalence was low. This is another example which shows that food is direct- 
Table 6. Logistic regression analysis of the data, who were taking food under un-hygienic conditions (street vendor's food). Those who are taking it in hygienic conditions were taken as referent.

\begin{tabular}{cccccccccc}
\hline S.No & Food Item & \multicolumn{2}{c}{ Daily } & \multicolumn{2}{c}{ Once/Week } & \multicolumn{2}{c}{ Once/Month } & Never \\
\hline & & $\begin{array}{c}\text { Odds } \\
\text { Ratio }\end{array}$ & $\begin{array}{c}\text { 95\% CI } \\
\text { Lower-Upper }\end{array}$ & $\begin{array}{c}\text { Odds } \\
\text { Ratio }\end{array}$ & $\begin{array}{c}\text { 95\% CI } \\
\text { Lower-Upper }\end{array}$ & $\begin{array}{c}\text { Odds } \\
\text { Ratio }\end{array}$ & $\begin{array}{c}\text { 95\% CI } \\
\text { Lower-Upper }\end{array}$ & $\begin{array}{c}\text { Odds } \\
\text { Ratio }\end{array}$ & $\begin{array}{c}\text { 95\% CI } \\
\text { Lower-Upper }\end{array}$ \\
\hline 1 & Chicken & 6.045 & $3.962-9.225$ & 2.556 & $1.537-4.249$ & 1.222 & $0.586-2.542$ & 0.935 & $0.442-1.982$ \\
2 & Fish & 5.177 & $3.331-8.048$ & 2.304 & $1.495-3.550$ & 1.831 & $0.921-3.639$ & 2.000 & $0.781-5.120$ \\
3 & Beef & 5.258 & $3.517-7.863$ & 3.135 & $1.862-5.278$ & 1.714 & $0.683-4301$ & 1.149 & $0.462-2.855$ \\
4 & Milk & 7.980 & $4.861-13.101$ & 2.483 & $1.529-4.031$ & 1.767 & $0.954-3.276$ & 1.000 & $0.512-1.953$ \\
5 & Fruits & 8.998 & $5.533-14.632$ & 2.218 & $1.354-3.634$ & 1.467 & $0.828-2.601$ & .921 & $0.415-2.043$ \\
6 & Vegetables & 5.455 & $3.660-8.128$ & 1.929 & $1.161-3.204$ & 1.333 & $0.535-3.320$ & 1.000 & $0.500-2.000$ \\
7 & Other food Items & 11.818 & $6.754-20.679$ & 3.273 & $1.795-5.965$ & 2.322 & $1.341-4.022$ & 1.119 & $0.494-2.534$ \\
\hline
\end{tabular}

ly not responsible for the transmission of bacteria but its preparation, handling, and consumption under unhygienic conditions, because fish also requires cooking $\left(73^{\circ} \mathrm{C}\right)$, and there are fewer chances of $H$. pylori contamination in properly cooked food items because Helicobacter pylori cannot survive at higher temperature [33]. Studies have showed that transmission of $H$. pylori infection can occur by inadvertent ingestion of food contaminated with cockroach excreta containing viable $H$. pylori. Cockroaches usually live in unsanitary places and there are possibilities for it to contaminate cooked food if it is not properly stored [34].

Similarly, the prevalence of Helicobacter pylori is higher in those subjects who consume beef in unhygienic conditions (street vendor's food). When we compared this with the subjects who consume the same food item under good hygienic conditions the prevalence was low. The result shows that unclean and unhygienic handling and preparation of the food supported the growth of the bacterium because earlier studies showed that Helicobacter pylori die rapidly in ground beef, whether refrigerated or frozen [35]. Consumption of beef also requires cooking and the required temperature for cooking beef is $62^{\circ} \mathrm{C}$. This study suggests that if beef is cooked, handled, and dispensed under conditions conducive to maintaining health, then there is no chance of transmission of Helicobacter pylori.

From the analyses we also found that the prevalence of Helicobacter pylori is higher in those who drink milk under unhygienic conditions (street vendor's food) as compared with those who drink milk under good hygienic conditions. There is a possibility of cow's milk transmitting $H$. pylori but it is confirmed that H.pylori does not survive in pasteurized milk [36]. The pasteurization generally involves heating of milk at 161 degrees Fahrenheit $\left(63^{\circ} \mathrm{C}\right)$ for 15 seconds. This temperature kills or inactivates the microorganisms that grow rapidly in milk [37].
The results obtained from our study confirms that $\mathrm{He}$ licobacter pylori is unable to survive in pasteurized milk but because of poor handling, use of unclean vessels for storing, drinking etc, possibly transmits this bacterium even after pasteurization [38].

The prevalence of Helicobacter pylori in those who consume fruits in unhygienic conditions (street vendor's food) without good hygiene practice was higher, when compared to subjects who consume it under good hygienic conditions.

This may be due to the reason that the fruits purchased from street vendors are contaminated by houseflies, the known vectors for transmission of Helicobacter pylori [39]. The fruits bought from street vendors if consumed without washing or if washed with contaminated water, can possibly transmit Helicobacter pylori, because Helicobacter pylori can survive more than 10 days in water and saline [27].

It has been specially recommended for travelers that fruits should be peeled shortly before consumption as a mean to decrease the risk of acquiring intestinal infection because consumption of fruits doesn't involve any sterilization technique [40].

Previous studies have shown that fruits show low prevalence of $H$. pylori. Increased consumption of vitamin $\mathrm{C}$ enriched fruits and fruits containing beta carotene showed protective effect against this infection. So consumption of fruits is good for prevention of

Helicobacter pylori infection if they are taken in good hygienic way [41,42].

Similarly when we found higher prevalence of Helicobacter pylori in those subjects who consume raw vegetables in unhygienic conditions (street vendor's food) when compared to those who consume it under good hygienic conditions. The results obtained shows that raw vegetables consumed under lesser hygienic conditions are found to be associated with $H$. pylori infection. Few earlier studies showed that $H$. pylori infection was asso- 
ciated with consumption of raw vegetables contaminated with water or soil or by a vector such as fly $[26,43]$.

Similarly higher prevalence of Helicobacter pylori was found in those who take food items like lassi, cut fruits and curry juices, etc in unhygienic conditions (street vendor's food), while those subjects who take it under good hygienic conditions showed lower preva- lence. The results obtained from our study are quite similar to earlier studies which showed high bacterial count in these food items. The probable reason for this may be poor personal hygiene, extended holding, constant handling and the use of substandard water and apparatus at different stages, as observed in street food practices [28] (Figures 2-4).

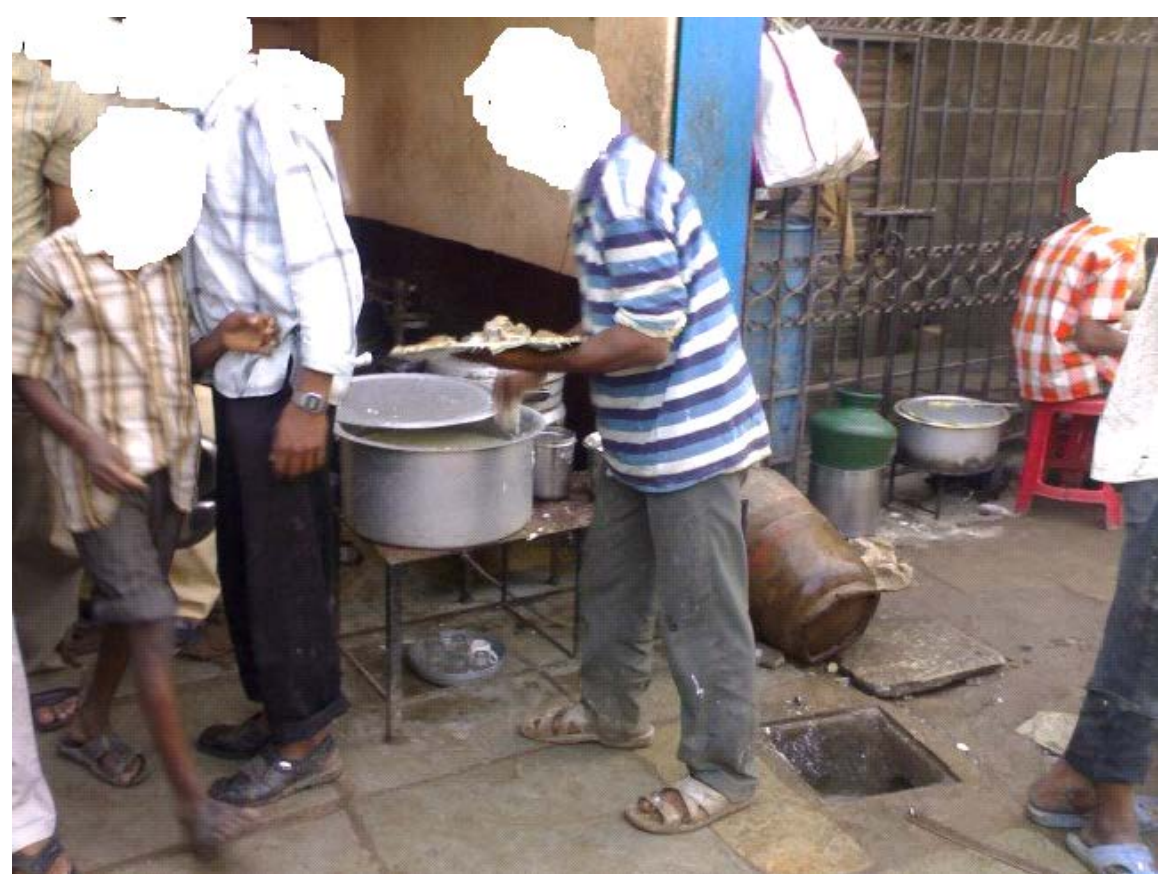

Figure 2. A Worker in food distributing Shop dispensing food items with bare hands with a drain open near it.

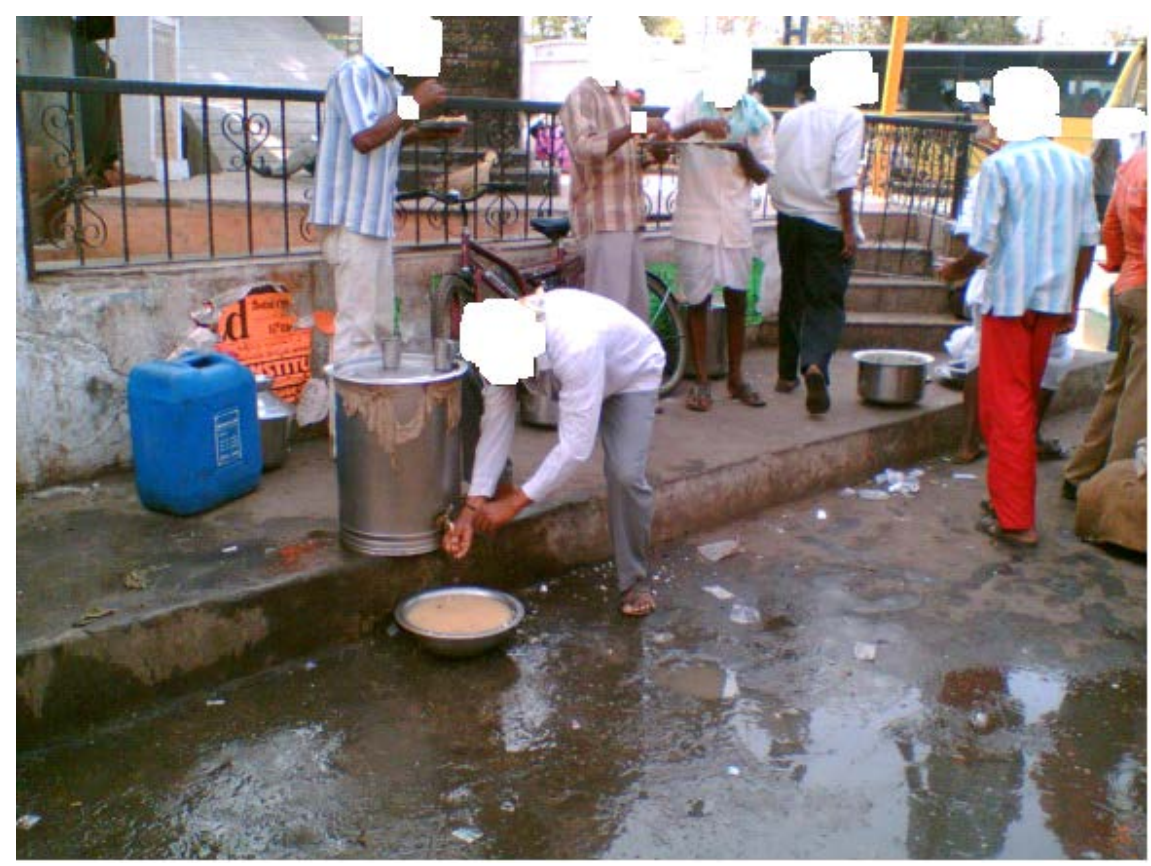

Figure 3. People taking food from street vendor's where the drinking glasses and food preparing vessels are kept open. 


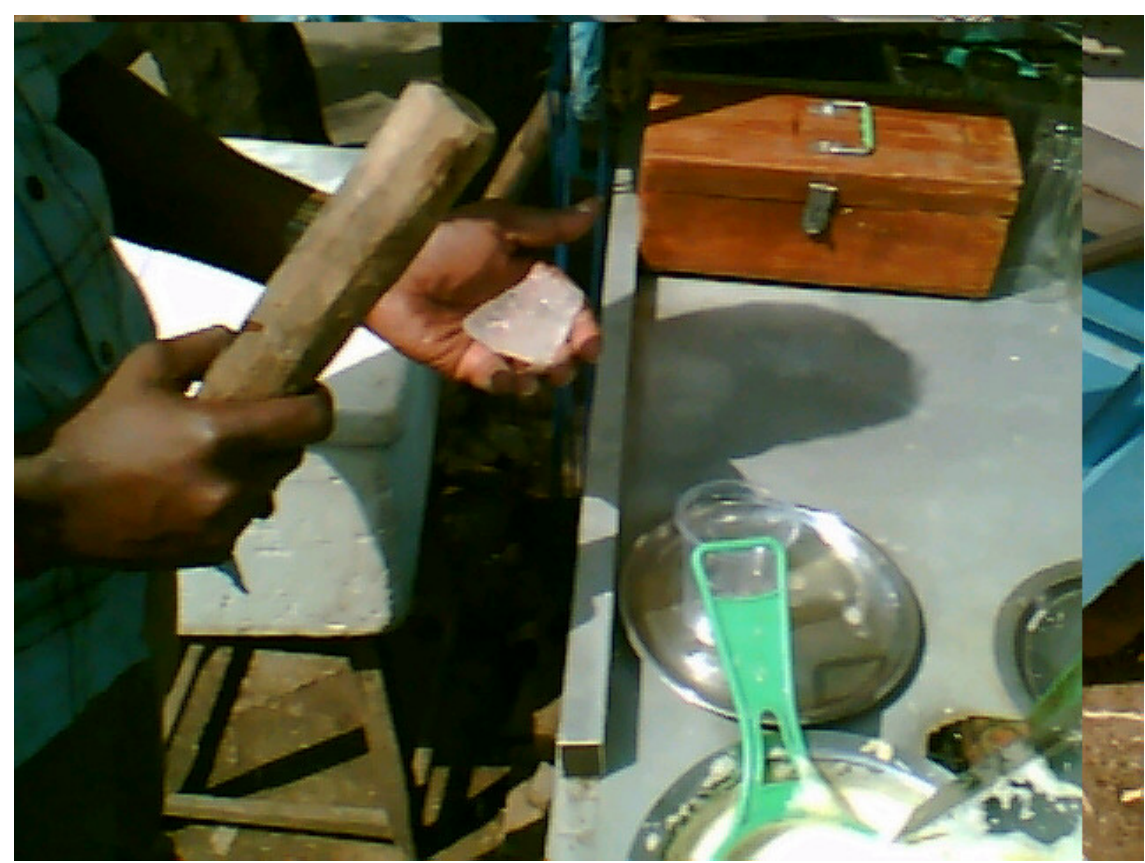

Figure 4. For Preparation of Fruit juices, the ice required is crushed in the hands; this picture is commonly seen during the preparation of food items by street vendors.

\section{CONCLUSION}

The results of this study show that the food we take in our daily lives is not directly involved in the transmission of Helicobacter pylori, but the hygiene during its preparation, handling and consumption, plays a vital role in the transmission of this bacterium even after cooking. Hence, maintaining good hygienic conditions while cooking, dispensing, and handling food items can minimize the chances of transmission of Helicobacter pylori. Our study also suggests us that street vendor's food is not harmful if good personal hygiene and clean environment are maintained. Educating street vendors in this regard can help in minimizing the chances of transmission of Helicobacter pylori to a great extent.

\section{ACKNOWLEDGEMENTS}

We would like to thank our colleagues at our department for their fruitful discussion during the research and their technical assistance during manuscript preparation.

\section{CONFLICT OF INTEREST}

No conflict of interest to declare.

Ethical Approval Ethical Approval Has taken From Hospital Ethical Committee for the study.

\section{REFERENCES}

[1] Warren, J.R. and Marshall, B.J. (1983) Unidentified curved bacilli on gastric epithelium in active chronic ga- stritis. Lancet, 1, 1273-1275.

[2] Correa, P., Mufioz, N., Cuello, C., Fox, J., Zavala, D. and Ruiz, B. (1989) The role of Campylobacter pylori in gastro-duodenal disease. In: Fenoglio-Preiser, C., Ed., Progress in Surgical Pathology, Field \& Wood, Philadelphia, 191-210. http://dx.doi.org/10.1007/978-3-662-12823-7_11

[3] Rugge, M., DiMario, F., Cassaro, M., Baffa, R., Farinati, F., Rubio, J., et al. (1993) Pathology of the gastric antrurn and body associated with Helicobacter pylori infection in non-ulcerous patients: Is the bacterium a promoter of intestinal metaplasia? Histopathology, 22, 9-15. http://dx.doi.org/10.1111/j.1365-2559.1993.tb00062.x

[4] Kuipers, F.J., Thijs, J.C. and Festen, H.P.M. (1995) The prevalence of Helicobacter pylori infection in peptic ulcer disease. Alimentary Pharmacology \& Therapeutics, 9, 59-69.

[5] Tytgat, G.N.J., Noach, L.A. and Rauws, E.A.J. (1993) Helicobacter pylori infection and duodenal ulcer disease. Gastroenterology Clinics of North America, 22, 127-140.

[6] Forman, D. (1995) The prevalence of Helicobacter pylori infection in gastric cancer. Alimentary Pharmacology \& Therapeutics, 9, 53-58.

[7] The EUROGAST Study Group. (1993) An international association between Helicobacter pylori infection and gastric cancer. Lancet, 341, 1359-1362. http://dx.doi.org/10.1016/0140-6736(93)90938-D

[8] Parsonnet, J., Hansen, S., Rodriguez, L., Gelb, A.B., Warnke, R.A., Jellum, E., et al. (1994) Helicobacter pylori infection and gastric lymphoma. The New England Journal of Medicine, 330, 1267-1271. http://dx.doi.org/10.1056/NEJM199405053301803

[9] Buiatti, E., Mufioz, N., Vivas, J., Cano, E., Peraza, S., 
Carillo, E., et al. (1994) Difficulty in eradicating Helicobacter pylori in a population at high risk for stomach cancer in Venezuela. Cancer Causes Control, 5, 249-254. http://dx.doi.org/10.1007/BF01830244

[10] Parsonnet, J. (1995) The incidence of Helicobacter pylori infection. Alimentary Pharmacology \& Therapeutics, 9, 45-51.

[11] Glupczynski, Y. and Burette, A. (1990) Drug therapy for Helicobacter pylori infection: problems and pitfalls. The American Journal of Gastroenterology, 85, 1545-1551.

[12] Coelho, L.G., Passos, M.C., Chausson, Y., Costa, E.L., Maia, A.F., Brandao, M.J., et al. (1992) Duodenal ulcer and eradication of Helicobacter pylori in a developing country. An 18-month follow-up study. Scandinavian Journal of Gastroenterology, 27, 362-366. http://dx.doi.org/10.3109/00365529209000088

[13] Goodman, K.J. and Correa, P. (1995) The transmission of Helicobacter pylori. A critical review of the evidence. International Journal of Epidemiology, 24, 875-887. http://dx.doi.org/10.1093/ije/24.5.875

[14] Sobala, G.M., Crabtree, J., Dixon, M.F., Schorah, C.J., Taylor, J.D., Rathbone, B.J., et al. (1991) Acute Helicobacter pylori infection: Clinical features, local and systemic immune response, gastric mucosal histology, and gastric juice ascorbic acid concentrations. Gut, 32, 14151418. http://dx.doi.org/10.1136/gut.32.11.1415

[15] Megraud, F. (1995) Transmission of Helicobacter pylori: faecal-oral versus oral-oral. Alimentary Pharmacology \& Therapeutics, 9, 85-91.

[16] Neale, K.R. and Logan, R.P. (1995) The epidemiology and transmission of Helicobacter pylori infection in children. Alimentary Pharmacology \& Therapeutics, 9, 7784.

[17] Fox, J.G., Blanco, M.C., Yan, L., Shames, B., Polidoro, D., Dewhirst, F.E., et al. (1993) Role of gastric pH in isolation of Helicobacter mustelae from the feces of ferrets. Gastroenterology, 104, 86-92.

[18] Fox, J.G., Paster, B.J., Dewhirst, F.E., Taylor, N.S., Yan, L.L., Macuch, P.J., et al. (1992) Helicobacter mustelae isolation from feces of ferrets: evidence to support fecal-oral transmission of a gastric helicobacter. Infection and Immunity, 60, 606-611.

[19] Thomas, J.E., Gibson, G.R., Darboe, M.K., Dale, A. and Weaver, L.T. (1992) Isolation of Helicobacter pylori from human faeces. Lancet, 340, 1194-1195. http://dx.doi.org/10.1016/0140-6736(92)92894-L

[20] Lee, A., Fox, J.G., Otto, G., Dick, E.H. and Krakowka, S. (1991) Transmission of Helicobacter spp. A challenge to the dogma of fecal-oral spread. Epidemiology and Infection, 107, 99-109. http://dx.doi.org/10.1017/S095026880004872X

[21] Blaser, M.J. (1987) Gastric Campylobacter-like organisms, gastritis and peptic ulcer disease. Gastroenterology, 93, 371-383.

[22] Shahamat, M., Paszco-Kolva, C., Yamamoto, H. and Colwell, R.R. (1989) Ecological studies of Campylobacter pylori. (Abstract). Klinische Wochenschrift, 67, 62-63.

[23] Shahamat, M., Vives-Rego, J., Paszco-Kolva, C., Pearson,
A.D. and Colwell, R.R. (1989) Survival of Campylobacter pylori in river water. (Abstract). Klinische Wochenschrift, 67, 63.

[24] West, A.P., Millar, M.R. and Tompkins, D.S. (1992) Effect of physical environment on survival of Helicobacter pylori. Journal of Clinical Pathology, 45, 228-231. http://dx.doi.org/10.1136/jcp.45.3.228

[25] Klein, P.D., Graham, D.Y., Gaillour, A., Opekun, A.R. and Smith, E.O. (1991) Water source as a risk factor for Helicobacter pylori infection in Peruvian children. Gastrointestinal Physiology Working Group. Lancet, 337, 1503-1506. http://dx.doi.org/10.1016/0140-6736(91)93196-G

[26] Hopkins, R.J., Vial, P.A., Ferreccio, C., Ovalle, J., Prado, P., Sotomayor, V., et al. (1993) Seroprevalence of Helicobacter pylori in Chile: Vegetables may serve as one route of transmission. The Journal of Infectious Diseases, 168, 222-226. http://dx.doi.org/10.1093/infdis/168.1.222

[27] Begue, R.E., Gonzales, J.L., Correa-Gracian, H. and Tang, S.C. (1998) Dietary Factors Associated with the Transmission of Helicobacter Pylori in Lima Peru. The American Journal of Tropical Medicine and Hygiene, 59, 637640.

[28] Chakravarty, I. and Canet, C. (1996) Street foods in Calcutta. Food. Nutrition and Agriculture, Publication no17/ 18, 30-37.

[29] Ahmed, K.S, Khan, A.A, Tiwari, S.K., Habeeb, A., Ahmed, I., Shaik, M.A., et al. (2006) Prevalence study to elucidate the transmission pathways of Helicobacter pylori at oral and gastroduodenal sites of a South Indian population. Singapore Medical Journal, 47, 291-296.

[30] Ahmed, K.S, Khan, A.A, Ahmed, I., Tiwari, S.K., Habeeb, A., Ahi, J.D., et al. (2007) Impact of household hygiene and water source on the prevalence and transmission of Helicobacter pylori: A South Indian perspective. Singapore Medical Journal, 48, 543-549.

[31] Hollingshead, A.B. (1957) Two factor index of social position. Yale University Press, New Haven.

[32] Jiang, X. and Doyle, M.P. (1998) Effect of environmental and substrate factors on survival and growth of Helicobacter pylori. Journal of Food Protection, 61, 929-933.

[33] FDA 2001 Food Code and Wisconsin Food Code: 3-401.11, Raw Animal Foods; 3-401.12, Microwave Cooking; 3-401.13, Plant Food Cooking for Hot Holding.

[34] Shigeyoshi, I., Masakazu, K., Yoshio, Y., Toshiro, Y., Atsushi, I., Hideyuki, K., et al. (2003) Vector Potential of Cockroaches for Helicobacter Pylori Infection. The American Journal of Gastroenterology, 98, 1500-1503.

[35] Stevenson, T.H., Bauer, N., Lucia, L.M. and Acuff, G.R. (2000) Attempts to isolate Helicobacter from cattle and survival of Helicobacter pylori in beef products. Journal of Food Protection, 63, 174-178.

[36] Fujimura, S., Kawamura, T., Kato, S., Tateno, H. and Watanabe, A. (2002) Detection of Helicobacter pylori in cow's milk. Letters in Applied Microbiology, 35, 504-507. http://dx.doi.org/10.1046/j.1472-765X.2002.01229.x

[37] Smith, P.W. (1981) "Milk Pasteurization” fact sheet number 57. US. Department of Agriculture Research Service, 
Washington DC.

[38] Quaglia, N.C., Dambrosio, A., Normanno, G., Parisi, A., Firinu, A., Lorusso, V. and Celanoa, G.V. (2007) Survival of Helicobacter pylori in artificially contaminated ultrahigh temperature and pasteurized milk. Food Microbiology, 24, 296-300.

http://dx.doi.org/10.1016/j.fm.2006.04.008

[39] Grubel, P., Hoffman, J.S., Chong, F.K., Burstein, N.A., Mepani, C. and Cave, D.R. (1997) Vector potential of houseflies (Musca domestica) for Helicobacter pylori. Journal of Clinical Microbiology, 35, 1300-1303.

[40] Centers for Disease Control and Prevention. (1997) Health hints for the traveler. Health information for international travel 1996-97. CDC, U.S. Department of Health and Human Services, Public Health Service, Atlanta, 177-196.

[41] Goodman, K.J., Correa, P., Tengana, A.H., Delany, J.P. and Collazos, T. (1997) Nutritional factors and Helicobacter pylori infection in Colombian children. Journal of Pediatric Gastroenterology \& Nutrition, 25, 507-515. http://dx.doi.org/10.1097/00005176-199711000-00004

[42] Jarosz, M., Dzieniszewski, J., Dabrowska-Ufniarz, E., Wartanowicz, M., Ziemlanski, S. and Reed, P.I. (1998) Effects of high dose vitamin $\mathrm{C}$ treatment on Helicobacter pylori infection and total vitamin $\mathrm{C}$ concentration in gastric juice. European Journal of Cancer Prevention, 7, 449-454. http://dx.doi.org/10.1097/00008469-199812000-00004

[43] Grubel, P., Huang, L., Masubuchi, N., Stutzenberger, F.J. and Cave, D.R. (1998) Detection of Helicobacter pylori DNA in houseflies (Musca domestica) on three continents. (Letter). Lancet, 352, 788-789. http://dx.doi.org/10.1016/S0140-6736(05)60683-6 